\title{
THE EMERGENCE OF A SYNERGETIC PARADIGM IN LINGUISTICS
}

\author{
Barno Abdullaeva
}

Department of Methodology Of Russian Language, Ferghana State University, Ferghana, Uzbekistan

\section{ABSTRACT}

The formation of a new transdisciplinary methodology - linguosynergetics - is noted in modern science. The article examines the origins and prospects, as well as the basic concepts of a new direction in modern linguistics. The possibility of applying a synergetic approach to the study of language, speech activity; an attempt is made to outline the boundaries and main tasks of a new field of research.

\section{KEYWORDS: - Synergetics, linguosynergetics, attractor, self-organization, metaphor.}

\section{INTRODUCTION}

Despite the fact that synergetics is a relatively new science of self-organization and self-development of complex systems, it finds new applications in various fields of science and technology. Many scientific works have already been written about it, in which an attempt is made to generalize the main laws of complex systems identified in the natural sciences.

The creator of the synergetic direction is G.Haken. He listed the following key provisions of this interdisciplinary scientific direction:

1. "The systems under study consist of several or many identical or heterogeneous parts that interact with each other.

2. These systems are nonlinear.

3. When considering systems of various origins, we are talking about open systems that are far from the state of equilibrium.

4. These systems are subject to internal and external fluctuations.
5. Systems may become unstable.

6. Qualitative changes are taking place.

7. Emergent new properties are found in these systems.

8. Spatial, temporal, spatio-temporal and/or functional structures arise.

9. Structures can be ordered or chaotic.

10. In many cases, mathematization is possible" [9. p. 55] Synergetics (from the Greek syergētikós joint action, mutualaction, etc.) is a new interdisciplinary direction in the study of systems consisting of a large number of components or subsystems that interact with each other in a complex way. As a result of such interaction, processes arise that lead to the selforganization of the system.

One of the most successful definitions of selforganizing systems was given by B.G.Yudin: "Selforganizing systems can be defined as systems capable of changing their structure with active interaction with the environment, while maintaining integrity and acting within the framework of the laws inherent in the environment, 
CURRENT RESEARCH JOURNAL OF PHILOLOGICAL SCIENCES 2(11):

60-63, November 2021

DOI: https://doi.org/10.37547/philological-crjps-02-11-15

ISSN 2767-3758

(C)2021 Master Journals

Crossref do

gil Google

Accepted $25^{\text {th }}$ November, 2021 \& Published $30^{\text {th }}$ November, 2021

choosing one of the possible lines of behavior. Such a system can take into account a large number of factors, each of which varies widely, i.e. it is able to control, regulate or manage extremely complex processes" [11. pp. 360-361].

The foundations of synergetics - the concepts of open, nonlinear systems and processes, deterministic chaos, dissipative structures and many others - were laid by G.Haken and I.R.Prigozhin [8. P. 2] and were further developed in various fields of natural science and humanities: physics, chemistry, biology, sociology, pedagogy, linguistics, as well as in art, culture, communication (E.N.Knyazeva, V.I.Arshinov, D.S.Chernavsky, V.G.Budanov, A.V. Voloshinov, I.A.Evin, V.G.Zinchenko) [4. p. 228].

In recent years, there has been a tendency towards convergence of natural sciences and humanities, and an increasing interest of humanitarians in the ideas and methods of synergetics. The synergetic understanding of many phenomena is gaining more and more followers in the world. Linguistics has not been left aside from this scientific direction either. A number of ideas of synergetics, such as the nonlinearity of the language system, openness and dynamic structurality, are being developed by linguists.

Synergetic worldview is characterized in philosophy as holistic, nonlinear, evolutionary. From the point of view of the interests of linguistics, such an understanding of reality canbe presented through the justification of the following postulate: Language "is a whole, unstable, changing, evolving world, which gives the right to speak about a certain instability in relation to it" [1. p. 20].

Linguistic synergetics is a new paradigm of language cognition as a human, social, biopsychic, cognitive and social phenomenon.
Linguosynergetics is based on an approach to language (discourse) as a self-organizing system, closely interconnected with the external environment (the consciousness of communicants and the general system of language), whose influence, along with the internal processes of the speech system, leads to the emergence of functional fluctuations (in terms of the linguosynergetics of "fluctuations"), deviation from the equilibrium state of the pragma-semantic field of discourse, supported by the so-called parameters of the order governing the functioning of the system. In response to the changes caused by the transformation, new, spontaneous properties arise in the semantic system, contributing to the further movement of discourse to the most ordered point of the system - the communicative goal - the "functional attractor" as the most favorable mode of functioning. "The surpluses of information appearing in the process of communication, being irrelevant and disorganizing elements of the discursive system, are subjected to "dissipation"they are dispersed into the external environment, from which, in turn, there is an influx into the system of resources that contribute to the repayment of semantic coherence, i.e., in the development of the system based on a circular causal relationship, there is a constant movement and interaction of pragmatic semantic components, which creates a complex synergetic functional space of discourse" [10. p. 176].

Linguosynergetics is not just a new stage, but an actively developing independent paradigm of systemic linguistics, which is based on an approach to language/speech/discourse as a dynamic selfregulated system. "Many ideas of modern linguistics, including English, are related to synergetic ones and testify to the timeliness of the emergence of this direction, integrating them into the system and directing them into a single channel" [7. p. 104]. 
CURRENT RESEARCH JOURNAL OF PHILOLOGICAL SCIENCES 2(11):

60-63, November 2021

DOI: https://doi.org/10.37547/philological-crjps-02-11-15

ISSN 2767-3758

(C)2021 Master Journals

Crossref do

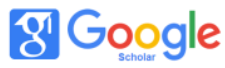

Accepted $25^{\text {th }}$ November, 2021 \& Published $30^{\text {th }}$ November, 2021

Thus, from the standpoint of linguosynergetics, the discourse system is characterized "as a dynamic nonlinear self-regulating system of discourse meanings formed through their speech expression" [6. p. 23].

Discourse is "an arbitrary fragment of text consisting of more than one sentence or an independent part of a sentence. Often, but not always, it concentrates around some basic concept; creates a general context describing actors, objects, circumstances, times, actions, etc., determined not so much by the sequence of sentences, as by the world common to the creator of the discourse and its interpreter, which is "built" in the course of the discourse unfolding...The initial structure for the discourse has the form of a sequence of elementary propositions connected by logical relations..." [3. p. 327].

It should be noted that, developing the foundations of the synergetic management of linguistics, we should not talk about the mechanical transfer of natural science terminology into the field of linguistic research, but about the appropriate use of necessary terms when developing new approaches to the analysis of functional constituent speech activity - based on previously established and sufficiently substantiated scientific ideas, but with their refraction in a new perspective.

The phenomenon of self-organization and selfregulation of language is an object of a whole range of concepts, varieties of dynamic approach to the study of linguistic units by J.K. Zipf, M. Svodesh; quantitative linguistics and typology (R.G. Piotrovsky, M.V. Arapov, V.T. Titov, J. Grinberg).

The subject of linguistic synergetics, according to R.G. Piotrovsky, is

"the discovery and study of the mechanisms of selforganization and self-regulation of language" [2. p. 65].
With the use of synergetic methodology, such complex human-dimensional systems as the mental lexicon (the psycholinguistic concept of the mental lexicon as a dynamic self-organizing system by A.A. Zalevskaya), the core of the mental lexicon (the concept of the core as a strange attractor attracting to itself all the trajectories of the evolution of the system by N.O. Zolotova), speech activity and the word (the direction of "linguosynergetics" developed by Barnaul psycholinguistic school), text (the concept of text as a self-organizing and selfdeveloping system N.L. Myshkina, the concept of a text as a natural energy object by G.G. Moskalchuk), a sign (the concept of semiosis as the transformation of energy into information by $E$. Taborsky).

The fundamental position of synergetic linguistics is the thesis about the disparity, instability, openness and nonlinearity of the language system.

Disequilibrium is a state of remoteness of a system from equilibrium (under the influence of certain forces), characterized by exchange processes between a dynamic system and the external environment. Unequal systems are able to perceive differences in the external environment and "take them into account" in their functioning.

Nonlinearity is the dependence of the properties of the system on the complex of processes that occur in it and on external influences. The notion of nonlinearity implies the possibility of different solutions or ways of evolution of the system under the existing initial conditions.

Some provisions of synergetics have been repeatedly stated, their applicability in linguistics has been analyzed, and the effectiveness of their application has been justified.

The essence of these provisions is as follows:

1. The ability of the system to self-organize is due to its non-equilibrium state and the presence of a 
CURRENT RESEARCH JOURNAL OF PHILOLOGICAL SCIENCES 2(11):

60-63, November 2021

DOI: https://doi.org/10.37547/philological-crjps-02-11-15

ISSN 2767-3758

(C)2021 Master Journals

crossref do) 8: Google

Accepted25 $5^{\text {th }}$ November, 2021 \& Published 30th November, 2021

hierarchy of subsystems capable of modeling each University, 2(10), 305-314. other and the environment.

2. There are attractors in self-organizing systems. In synergetics, they "lead to a common denominator" a large variety of explanations of how the generation of text and con- text occurs. For such explanations, the concepts of extralinguistic conditions, intentions of communicants, linguistic personality, linguistic worldview, etc. are involved.

Selforganization is a fundamental concept of synergetics and means the transition from chaos to a structured state, leading to the transition of the system to a stable state - an attractor.

\section{REFERENCES}

1. Bazylev, V. N. Avtoportrety politikov: ot psihopojetiki k psi- hopolitike // Politicheskij diskurs v Rossii. Materialy rabochego sovewanija. M., 1999. 17-24.

2. German, I. A. Lingvosinerge- tika: Monografija. Barnaul : Izd-vo Altajskoj akademii jekonomiki i prava, 2000.168 s.

3. Dem'jankov, V. Z. 1982a - Konvencii, pravila i strategii ob- wenija: (Interpretirujuwij podhod k argumentacii) // Izv. AN SSSR. Ser. lit. i jazyka, 1982. T. 41. 4. S.327-337.

4. Drozhawih, N. V. Lingvosiner- getika: istoki i perspektivy // Vest- nik Tjumenskogo gosudarstven- nogo universiteta. 2009. №1. S. 227-234.

5. Knjazeva, E. N. Antropnyj prin- cip v sinergetike // Voprosy filo- sofii. 1997. № 3.

6. Ponomarenko, E. V. 0 principah sinergeticheskogo issledovanija rechevoj dejatel'nosti/ E.V. Pono- marenko// Voprosy filologii. 2007.

№ 1. S. 14-23

7. Ismatullaeva, N. R. (2020). Methods of Elimination of Lexical Gaps in Translation (on example of Chinese and Uzbek languages). Scientific Bulletin of Namangan State 